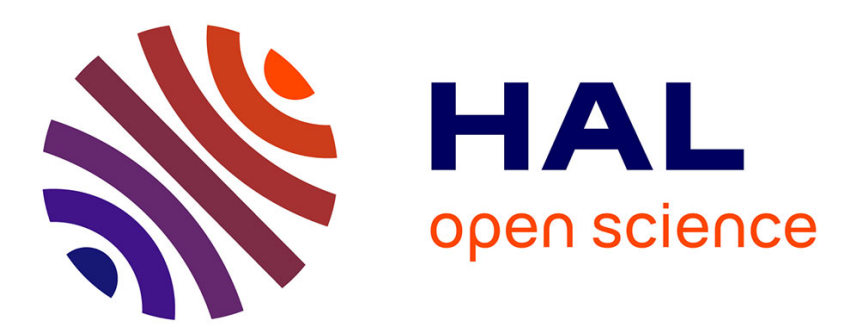

\title{
Is raw milk microbiota influenced by the use of live yeast (Saccharomyces cerevisiae) as ruminant feed additive?
}

Ester Grilli, Helene Tormo, Mattia Fustini, Chloe Deneufbour, Marina Losio, Andrea Formigoni, Frédérique Durand, Henri Durand

\section{- To cite this version:}

Ester Grilli, Helene Tormo, Mattia Fustini, Chloe Deneufbour, Marina Losio, et al.. Is raw milk microbiota influenced by the use of live yeast (Saccharomyces cerevisiae) as ruminant feed additive? International Journal of Dairy Science, 2016, 11 (3), pp.124-129. 10.3923/ijds.2016.124.129 . hal01601365

\section{HAL Id: hal-01601365 https://hal.science/hal-01601365}

Submitted on 27 May 2020

HAL is a multi-disciplinary open access archive for the deposit and dissemination of scientific research documents, whether they are published or not. The documents may come from teaching and research institutions in France or abroad, or from public or private research centers.
L'archive ouverte pluridisciplinaire HAL, est destinée au dépôt et à la diffusion de documents scientifiques de niveau recherche, publiés ou non, émanant des établissements d'enseignement et de recherche français ou étrangers, des laboratoires publics ou privés. 


\title{
Short Communication
}

\section{Is Raw Milk Microbiota Influenced by the use of Live Yeast (Saccharomyces cerevisiae) as Ruminant Feed Additive?}

\author{
${ }^{1}$ Ester Grilli, ${ }^{2}$ Helene Tormo, 'Mattia Fustini, ${ }^{2}$ Chloé Deneufbourg, ${ }^{3}$ Marina Losio, ${ }^{1}$ Andrea Formigoni, \\ ${ }^{4}$ Frederique Chaucheyras-Durand and ${ }^{4}$ Henri Durand \\ ${ }^{1}$ DIMEVET, University of Bologna, 40064 Ozzano Emilia, Italy \\ ${ }^{2}$ Université de Toulouse-INPT, Ecole d'Ingénieurs de Purpan, 75 voie du TOEC, 31076 Toulouse cedex 3, France \\ ${ }^{3}$ Istituto zooprofilattico Sperimentale Della Lombardia E Dell' Emilia Romagna, 2514 Brescia, Italy \\ ${ }^{4}$ Lallemand Animal Nutrition, 19 rue des Briquetiers, 31702 Blagnac cedex, France
}

\begin{abstract}
Live Saccharomyces cerevisiae yeast strains are widely used as feed additives for dairy cows. Although, perfectly safe and applied in several food processes, the potential contamination of milk by the strain and more generally its possible influence on the microbial profile of milk could be questioned, this concerns particularly traditional cheeses made with raw milk. In an attempt to address these questions, two experiments were performed: A trial in an experimental farm, where two groups of cows, one receiving yeast supplementation and the other one being an unsupplemented control, were compared and a field trial where herds received alternatively yeast-supplemented and control diets. In both cases, viable counts of different microbial groups, including yeasts and molds in general and S. cerevisiae in particular were analysed in tank milk and results from supplemented groups or periods were compared with control ones. No viable S. cerevisiae were detected in any of the samples analysed. Moreover, no noticeable differences in the microbial profiles were observed. This applies also to the evolution of the microbial composition during an experimental cheese processing trial. These data suggest that live yeast additive distributed to dairy cows does not influence milk microbial composition and cheese-making abilities.
\end{abstract}

Key words: Dairy cow, milk, cheese, live yeast, feed additive

Received: January 13, $2016 \quad$ Accepted: March 01, $2016 \quad$ Published: April 15, 2016

Citation: Ester Grilli, Helene Tormo, Mattia Fustini, Chloé Deneufbourg, Marina Losio, Andrea Formigoni, Frederique Chaucheyras-Durand and Henri Durand, 2016. Is raw milk microbiota influenced by the use of live yeast (Saccharomyces cerevisiae) as ruminant feed additive? Int. J. Dairy Sci., 11: $124-129$.

Corresponding Author: Frederique Chaucheyras-Durand, Lallemand Animal Nutrition, 19 Rue des Briquetiers, 31702 Blagnac cedex, France Tel: 33689568924 Fax: 33473624581

Copyright: @ 2016 Ester Grilli et al. This is an open access article distributed under the terms of the creative commons attribution License, which permits unrestricted use, distribution and reproduction in any medium, provided the original author and source are credited.

Competing Interest: The authors have declared that no competing interest exists.

Data Availability: All relevant data are within the paper and its supporting information files. 


\section{INTRODUCTION}

In the last present years, the use of antibiotics and chemical growth promoters in livestock production has been dramatically reduced, as a result of both regulatory constraints and consumer demand. To fulfill the need for optimizing the management of intensive animal production, more natural solutions based on plant or microbial ingredients have been proposed. Live microorganisms known as "Probiotics" or "Direct Fed Microbials" are one of the most rapidly developing categories of these natural feed supplements (Chaucheyras-Durand and Durand, 2010).

In dairy production, the most thoroughly used microbial feed supplement is live yeast, mostly of the Saccharomyces cerevisiae species. This species being traditionally used for centuries in food processes (baking, brewing, wine making etc.) is considered as very safe (EFSA., 2007) and is generally well accepted by both farmers and consumers. Many published studies have described the beneficial effects of daily yeast supplementation on milk yield (Desnoyers et al., 2009; De Ondarza et al., 2010), or milk composition, in particular on milk fat percentage (Moallem et al., 2009; DeVries and Chevaux, 2014). For some strains, modes of action have been described, such as direct interactions with ruminal microbial communities or modulation of ruminal environment that change microbiota balance in a more favorable way for the animal (Chaucheyras-Durand et al., 2008).

In some European countries (notably France, Italy or Spain), a significant part of cheeses available on the market is traditionally made with raw milk. The microbiological quality of such products, partly resulting from that of milk, is of paramount importance. Indeed, some microorganisms can be detrimental, i.e., pathogenic, toxinogenic or provoking flavor defects, some others are essential to the proper development of required organoleptic properties (taste, texture and colour) during cheese maturation (Desmasures and Beuvier, 2011).

Although, various yeasts and molds species, including Saccharomyces sp., have been identified in raw milk (Panelli et al., 2013, 2014; Montel et al., 2014), S. cerevisiae sensu stricto species has never been mentioned. Therefore, the potential presence of $S$. cerevisiae in milk when using this species as a feed supplement could be regarded as questionable, even considering its safety and inability to metabolize lactose (Chen and Chiger, 1985). On another aspect, since the traditional cheese processes, in particular the Protected Designation of Origin (PDO) cheeses, rely on microbes naturally present in raw milk (Montel et al., 2014), the potential impact on milk microbial profile when using feed additives acting on the cow gut microbiota could be questioned.

In this context, compared microbial populations in milk collected from cows supplemented with live yeast vs controls, by using two distinct approaches. First, a trial was performed in an experimental farm with well controlled conditions, where the herd was randomly split into two groups, one being supplemented and the other one being a control. Secondly, a field trial involving five farms where periods of supplementation alternated with control periods was carried out.

\section{MATERIALS AND METHODS}

\section{Trial 1: University farm trial with contemporaneous group comparison \\ Trial design: The study was conducted with 40 Holstein dairy} cows in the experimental farm of the University of Bologna, Italy. The lactating herd was divided into 2 groups, homogeneous for milk yield, fat and protein content, parity and body weight. Criteria to select cows undergoing the experiment were, among others, parity number $<4$ and $30<$ days of pregnancy $<160$.

Animals received the same diet under the form of Total Mixed Ration (TMR) that was formulated to meet the requirements of high producing cows according to NRC (2001). The diet was based on hay (43\% of the TMR) and did not include any silage in accordance to the operating instructions to produce Parmigiano Reggiano cheese. The experimental product (Saccharomyces cerevisiae CNCM I-1077, Lallemand Animal Nutrition, Blagnac, France) was provided at the dose of $2 \times 10^{10} \mathrm{CFU}$ of live yeast/head/day in a premixture to be included in the diet at $100 \mathrm{~g} / \mathrm{head} /$ day. The control group received $100 \mathrm{~g} / \mathrm{head} /$ day of a placebo which consisted in the carrier (limestone) used in the premixture.

The duration of the trial was 63 days, including a 14 days observation period with both groups receiving the same diet without yeast supplementation, followed by a 42 days period with one group receiving the yeast supplementation and the other group the placebo. At the end of the trial, the groups were kept separated during 7 days and the parameters continued to be recorded as described below.

During the whole trial, the following parameters were recorded daily: Group feed intake, individual milk production and composition (Afilab NIR technology), individual body weight. The milk was collected in two distinct tanks, one for 
Int. J. Dairy Sci., 11 (3): 124-129, 2016

Table 1: Specific media and incubation conditions used to enumerate different microbial categories in Trial 1

\begin{tabular}{|c|c|c|c|c|}
\hline Microbial category & Medium & Incubation temperature $\left({ }^{\circ} \mathrm{C}\right)$ & Incubation time (h) & Reference \\
\hline Yeasts & Sabouraud Chloramphenicol agar & 25 & 72 & Carlier (1948) \\
\hline Enterobacteria & Violet Red Bile Glucose agar & 37 & 24 & ISO (2004) \\
\hline Mesophilic bacteria & PCA with $1 \mathrm{~g} \mathrm{~L}^{-1}$ of skim milk & 30 & 24 & Franciosi et al. (2011) \\
\hline Mesophilic lactobacilli & MRS agar & 30 & 48 & De Man et al. (1960) \\
\hline Thermophilic lactobacilli & MRS agar & 42 & 48 & De Man et al. (1960) \\
\hline Mesophilic lactococci & M17 agar & 30 & 48 & Terzaghi and Sandine (1975) \\
\hline Thermophilic streptococci & M17 agar & 42 & 48 & Terzaghi and Sandine (1975) \\
\hline
\end{tabular}

Table 2: Specific media and incubation conditions used to enumerate different microbial categories in Trial 2

\begin{tabular}{|c|c|c|c|c|}
\hline Microbial category & Medium & Incubation temperature $\left({ }^{\circ} \mathrm{C}\right)$ & Incubation time (h) & Reference \\
\hline Total mesophilic flora & PCA skim milk agar & 30 & 72 & ISO (2003) \\
\hline \multirow[t]{2}{*}{ Gram negative bacteria } & PCA skim milk agar+inhibitors & & & \\
\hline & (purple cristal and vancomycin) & 30 & 48 & ISO (2003) \\
\hline Lactic acid bacteria & MRS agar & 30 & 72 & De Man et al. (1960) \\
\hline Enterococci & Bile Esculin agar & 37 & 24 & Swan (1954) \\
\hline Enterobacteria & Violet Red Bile Glucose agar & 37 & 24 & ISO (2004) \\
\hline Pseudomonas sp. & CFC & 25 & 48 & Mead and Adams (1977) \\
\hline Yeasts and molds & Sabouraud Chloramphenicol agar & 25 & 72 & Carlier (1948) \\
\hline Saccharomyces cerevisiae & Lysine agar (1) & 25 & 7 days & Morris and Eddy (1957) \\
\hline
\end{tabular}

Lysine agar medium is usually recommended as a selective medium for "wild yeasts" as opposed to Saccharomyces species used for brewing or baking. On this medium, the latter grows very slowly and gives small, white colonies while the former generally grows vigourously and forms larger colonies. However $S$. cerevisiae colonies are visible even on a background of wild yeasts

each group, through separate piping circuits. Individual milk production data in the 2 groups were compared with t-test (Statistica 10.0, Vicenza, Italy).

Microbiological analysis of milk: For the purpose of evaluating the potential effect of yeast supplementation on the microbial populations playing a role in cheese organoleptic properties, it was chosen to focus on metabolically active biomass and on functional groups rather than taxonomy. That is why the viable counts determination by plating on specific media was preferred to molecular techniques. At day 49, 56 and 63, samples of tank milk from both groups were taken aseptically to be analysed for microbial content. On the same days, viable count determinations were performed on specific media as described in Table 1.

In addition, a cheese processing trial according to Parmiggiano Reggiano traditional process was performed on a $300 \mathrm{~kg}$ batch of milk from the treated and control groups at days 49 and 56, respectively. The process involves a curdling step induced by rennet addition, a cooking step i.e., heating of the curd for $10-12$ min at $56^{\circ} \mathrm{C}$ and a natural cooling step. At each step of the process (milk pre-curdling, curd before cooking, cooked curd) samples were taken and microbial counts were performed as described above.

\section{Trial 2: Multi-farm trial with alternative periods of treatment}

Trial design: Five dairy farms in the South-West of France (Haute-Garonne and Tarn Departments) were selected as being geographically close to the lab where analyses were performed and comparable to each other as regards with herd size, management and feeding practices. The number of lactating cows (Holstein breed) per farm ranged from 45-77, the milk yield per cow ranged from 8000-10000 kg per year. All rations were total mixed rations based on corn silage and concentrates in comparable proportions.

The duration of the trial was 15 weeks, divided into 5 periods of 3 weeks each. During the first period, three farm managers (farms coded A, C and F) were asked to supplement their ration with live yeast (Saccharomyces cerevisiae CNCM 1-1077, Lallemand Animal Nutrition, France) at the dose of $2 \times 10^{10} \mathrm{CFU} /$ head/day, introduced in the TMR as a premixture. The other two ( $B$ and $R$ ) did not use yeast supplementation. During the second period, the supplementation concerned the latter farms ( $B$ and $R$ ), while the former ( $A, C$ and $F)$ interrupted it. This switch was repeated during the third and fourth periods. During the last period, none of the farms used yeast; this period was intended to evaluate potential carry-over effects of the yeast supplementation.

Microbiological analysis of milk: In each farm, samples of milk were taken aseptically from the tank every week at the same time. The No. of milkings varied from 1-4 between farms but were constant within a given farm. The samples were immediately brought to the lab in refrigerated containers to be analyzed within $6 \mathrm{~h}$ at maximum.

On each sample, microbial counts were performed by plating on specific agar media as described in Table 2. 
Int. J. Dairy Sci., 11 (3): 124-129, 2016

\begin{tabular}{|c|c|c|c|c|c|c|c|c|}
\hline Day of sampling & Group & $\begin{array}{l}\text { Entero } \\
\text { bacteria }\end{array}$ & $\begin{array}{l}\text { Mesophilic } \\
\text { bacteria }\end{array}$ & Yeasts & $\begin{array}{l}\text { Mesophilic } \\
\text { lactococci }\end{array}$ & $\begin{array}{l}\text { Thermophilic } \\
\text { streptococci }\end{array}$ & $\begin{array}{l}\text { Mesophilic } \\
\text { lactobacilli }\end{array}$ & $\begin{array}{l}\text { Thermophilic } \\
\text { lactobacilli }\end{array}$ \\
\hline \multirow[t]{2}{*}{49} & Control & 2.9 & 4.0 & 2.2 & 3.7 & 3.4 & 2.9 & 2.3 \\
\hline & Treated & 2.5 & 4.6 & 2.3 & 4.3 & 3.2 & 3.1 & 2.3 \\
\hline \multirow[t]{2}{*}{56} & Control & 1.1 & 4.2 & $<1$ & 3.8 & 3.6 & 3.4 & 2.6 \\
\hline & Treated & 1.9 & 4.8 & 1.6 & 4.5 & 4.5 & 3.3 & 2.9 \\
\hline \multirow[t]{2}{*}{$63^{*}$} & Control & 2.4 & 3.9 & 2.6 & 3.6 & 3.2 & 3.0 & 2.0 \\
\hline & Treated & 2.2 & 4.5 & 2.7 & 4.2 & 3.6 & 3.4 & 2.6 \\
\hline \multirow[t]{2}{*}{ Mean $\pm S D$} & Control & $2.1 \pm 0.9$ & $4.0 \pm 0.2$ & $1.9 \pm 0.8$ & $3.7 \pm 0.1$ & $3.4 \pm 0.2$ & $3.1 \pm 0.3$ & $2.3 \pm 0.3$ \\
\hline & Treated & $2.2 \pm 0.3$ & $4.6 \pm 0.2$ & $2.2 \pm 0.6$ & $4.3 \pm 0.2$ & $3.8 \pm 0.7$ & $3.3 \pm 0.2$ & $2.6 \pm 0.3$ \\
\hline
\end{tabular}

*samples taken one week after the end of yeast distribution to "treated" group

Table 4: Microbial profile of tank milk samples from Trial 2

\begin{tabular}{|c|c|c|c|c|c|c|c|c|}
\hline Farm & Yeast distribution & Entero bacteria & Mesophilic bacteria & Yeasts and molds & Lactic acid bacteria & Gram negative & Enterococci & Pseudomonas \\
\hline \multirow[t]{2}{*}{$\bar{A}$} & No & $2.2 \pm 0.4$ & $4.5 \pm 0.9$ & $2.4 \pm 0.6$ & $2.9 \pm 0.6$ & $3.7 \pm 0.5$ & $3.0 \pm 0.5$ & $3.5 \pm 0.5$ \\
\hline & Yes & $2.1 \pm 0.7$ & 4. $4 \pm 0.7$ & $2.7 \pm 0.3$ & $2.9 \pm 0.5$ & $3.1 \pm 0.3$ & $3.1 \pm 0.9$ & $3.8 \pm 0.8$ \\
\hline \multirow[t]{2}{*}{ B } & No & $1.2 \pm 0.6$ & $4.5 \pm 1.0$ & $3.2 \pm 0.8$ & $2.5 \pm 1.0$ & $2.2 \pm 1.2$ & $3.1 \pm 0.8$ & $2.8 \pm 1.5$ \\
\hline & Yes & $0.9 \pm 0.7$ & $3.9 \pm 0.5$ & $3.0 \pm 0.4$ & $2.3 \pm 0.6$ & $1.9 \pm 1.7$ & $2.6 \pm 0.5$ & $2.3 \pm 1.4$ \\
\hline \multirow[t]{2}{*}{ C } & No & $1.1 \pm 1.0$ & $3.6 \pm 0.6$ & $2.6 \pm 0.6$ & $2.0 \pm 0.2$ & $1.4 \pm 1.2$ & $2.6 \pm 0.4$ & $1.3 \pm 0.9$ \\
\hline & Yes & $1.1 \pm 0.6$ & $4.0 \pm 0.9$ & $2.7 \pm 0.6$ & $1.9 \pm 0.7$ & $0.5 \pm 1.0$ & $2.9 \pm 0.5$ & $1.2 \pm 1.0$ \\
\hline \multirow[t]{2}{*}{$\mathrm{F}$} & No & $1.2 \pm 0.9$ & $3.7 \pm 0.2$ & $2.8 \pm 0.2$ & $1.8 \pm 0.2$ & $2.3 \pm 0.8$ & $2.3 \pm 0.2$ & $1.9 \pm 0.4$ \\
\hline & Yes & $1.2 \pm 0.8$ & $4.0 \pm 0.8$ & $2.8 \pm 0.2$ & $1.3 \pm 0.9$ & $2.5 \pm 0.9$ & $2.2 \pm 0.3$ & $2.1 \pm 1.8$ \\
\hline \multirow[t]{2}{*}{$\mathrm{R}$} & No & $1.4 \pm 0.2$ & $4.4 \pm 0.5$ & $3.3 \pm 0.3$ & $1.9 \pm 0.5$ & $2.3 \pm 1.4$ & $2.9 \pm 0.4$ & $2.6 \pm 0.5$ \\
\hline & Yes & $1.3 \pm 0.4$ & $3.9 \pm 0.6$ & $3.4 \pm 0.8$ & $2.2 \pm 0.5$ & $2.2 \pm 1.3$ & $3.1 \pm 0.3$ & $2.1 \pm 0.5$ \\
\hline \multirow[t]{2}{*}{ Pool } & No & $1.4 \pm 0.9$ & $4.1 \pm 0.8$ & $2.8 \pm 0.6$ & $2.2 \pm 0.7$ & $2.4 \pm 1.4$ & $2.7 \pm 0.6$ & $2.4 \pm 1.1$ \\
\hline & Yes & $1.3 \pm 0.7$ & $4.0 \pm 0.6$ & $3.0 \pm 0.5$ & $2.1 \pm 0.8$ & $2.0 \pm 1.4$ & $2.8 \pm 0.6$ & $2.3 \pm 1.3$ \\
\hline
\end{tabular}

(Mean \pm SD of 9 weekly samples taken during control periods, 6 samples during yeast distribution periods, in $\log _{10} \mathrm{CFU} \mathrm{mL}^{-1}$ )

The results obtained during the yeast supplementation periods in a given farm were compared to those during the control periods in the same farm, using ANOVA with Fisher test as a statistical tool.

\section{RESULTS AND DISCUSSION}

Zoo technical parameters: For Trial 1, the group receiving yeast supplementation produced $1.3 \mathrm{~kg}$ more fat corrected milk (27.1 vs $25.8 \mathrm{~kg} \mathrm{day}^{-1}$ ) and energy corrected milk ( 27.4 vs $\left.26.1 \mathrm{~kg} \mathrm{day}^{-1}\right)(\mathrm{p}<0.05)$ as compared to the control group. A slight but significant increase in fat content was also observed (3.24 vs $3.18 \%, p<0.05$ ). For Trial 2 , the design did not allow to accurately compare the production between yeast supplementation periods and control periods. However, no notable variations in the production parameters were observed in between periods.

\section{Monitoring of milk contamination by live yeast supplement:}

In Trial 2, the potential presence of Saccharomyces cerevisiae viable cells was sought for in milk samples, by plating on lysine agar medium. No colonies harbouring the characteristic shape and color of the S. cerevisiae CNCM l-1077 strain, plated as a control at the same time, were detected in any of the 75 milk samples analysed.
Microbial profile of raw milk: The results of the microbiological analysis of milk samples from Trial 1 are shown in Table 3. The highest viable counts were observed for total mesophilic bacteria (3.9-4.8 $\log _{10} \mathrm{CFU} \mathrm{mL} \mathrm{mL}^{-1}$ ), closely followed by mesophilic lactococci (3.6-4.5 $\left.\log _{10} \mathrm{CFU} \mathrm{mL}{ }^{-1}\right)$. This tends to indicate that lactococci are the main constituents of the mesophilic flora. These concentrations are in agreement with those described in the literature (Bouton et al., 2005; Marion et al., 2008). Yeasts and Enterobacteria were found at much lower concentrations $\left(<1-2.7\right.$ and 1.1-2.9 $\log _{10} \mathrm{CFU} \mathrm{mL}{ }^{-1}$, respectively). However, max values for these two groups appear to be higher in our samples than those reported elsewhere (Bouton etal., 1998; Marion etal., 2008; Desmasures and Beuvier, 2011). This may reflect the specific environmental conditions of the farm (e.g., bedding and feeding practices) and/or differences in the methods of analysis.

When comparing the microbial profiles between the two groups of cows, although the small No. of samples did not allow a proper statistical analysis, no notable differences were observed.

In Table 4, the microbial profiles of the raw milk collected during control and yeast supplementation period in each farm of Trial 2 are displayed.

Fairly consistent viable counts were found for each microbial category, with acceptable variations between 


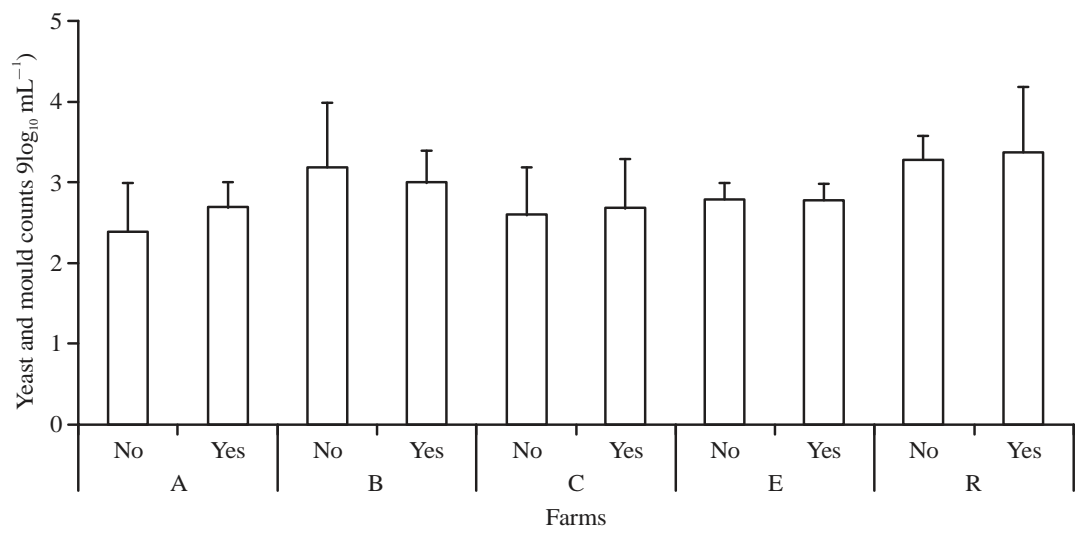

Fig. 1: Viable yeast and mould counts in tank milk collected in the different farms during non-supplemented (no) and supplemented (yes) periods of Trial 2. Means and SDs are shown

Table 5: Evolution of microbial profiles of milk and curd during cheese processing in Trial $1\left(\log _{10} \mathrm{CFU} \mathrm{mL}^{-1}\right)$

\begin{tabular}{llccccccc}
\hline Matrix & Group & $\begin{array}{c}\text { Entero } \\
\text { bacteria }\end{array}$ & $\begin{array}{l}\text { Mesophilic } \\
\text { bacteria }\end{array}$ & Yeasts & $\begin{array}{c}\text { Mesophilic } \\
\text { lactococci }\end{array}$ & $\begin{array}{c}\text { Thermophilic } \\
\text { streptococci }\end{array}$ & $\begin{array}{c}\text { Mesophilic } \\
\text { lactobacilli }\end{array}$ & $\begin{array}{c}\text { Thermophilic } \\
\text { lactobacilli }\end{array}$ \\
\hline Milk pre-curdling & Control & 5.6 & 6.7 & 3.8 & 6.6 & 6.6 & 6.4 & 3.7 \\
Curd before cooking & Treated & 2.9 & 5.1 & 3.4 & 4.7 & 4.3 & 4.3 & 3.0 \\
& Control & 4.8 & 6.5 & 3.8 & 6.4 & 6.4 & 6.4 \\
Cooked curd & Treated & 1.9 & 4.7 & 2.6 & 4.3 & 4.2 & 3.8 & 3.3 \\
& Control & 0.8 & 5.5 & $<1$ & 5.4 & 5.4 & 4.2 & 4.3 \\
& Treated & $<1$ & 4.2 & $<1$ & 3.5 & 4.6 & 2.3 \\
\hline
\end{tabular}

samples within a farm on the one hand and between farms on the other hand.

As in Trial 1, mesophilic bacteria appear as the major microbial group and the levels observed are in line with published data. Gram negative bacteria, lactic acid bacteria, Enterobacteria, enterococci and pseudomonas are also found at concentrations comparable to published results (references cited above). Similarly, to Trial 1, yeast and molds counts were detected at higher levels, which might reflect methodological or environmental differences.

When comparing the results obtained during the yeast supplementation periods in a given farm to those during the control periods in the same farm, no significant differences ( $p>0.05$ ) were found.

No clear cut difference between supplemented and non-supplemented periods can be observed on yeast and mold counts (Fig. 1). This corroborates the findings that yeast supplementation through the ration does not appear to influence the fungal population in raw milk.

\section{Evolution of microbial profiles during cheese processing:}

The effect of processing on the evolution of the microbial profiles was similar in both groups (Table 5). The cooking step resulted in a marked decrease of mesophilic bacteria counts and a dramatic drop in Enterobacteria and yeasts, the latter was even not detected in the cooked curds. Thermophilic streptococci were less affected by cooking and thermophilic lactobacilli remained essentially unchanged. These results are in accordance with those of previously published study, where a decrease in mesophilic flora and not in thermophilic bacteria after the cooking step were also described (Coppola et al., 2000; De Dea Lindner et al., 2008).

\section{CONCLUSION}

The present study aimed at studying the potential effect of live yeast additive daily supplementation to dairy cows on the microbiological properties of raw milk used in traditional cheese manufacturing. First of all, the question of possible passage of viable yeast cells in milk was addressed. By using a semi-selective cultural method, live $S$. cerevisiae cells were never detected in the samples analysed. It appears that although being very ubiquitous in nature, $S$. cerevisiae does not find a favorable habitat in raw milk; one of the reasons is probably linked to its lack of capacity to metabolize lactose.

The next question concerned more generally the change in milk microbial profile potentially induced by yeast supplementation. As far as the various microbial groups targeted in this study are concerned, no differences were observed between milk obtained from yeast supplemented cows vs control cows. This applies both in raw milk and in curd during cheese processing. 


\section{REFERENCES}

Bouton, Y., P. Guyot and P. Grappin, 1998. Preliminary characterization of microflora of comte cheese. J. Applied Microbiol., 85: 123-131.

Bouton, Y., N. Desmasures and E. Beuvier, 2005. Faut-il privilegier la quantite ou la nature de la flore du lait? In Fiche de Synthese du Reseau Fromages de Terroir, 1. http:// www.pole -fromager-aoc-mc.org/doc/Quantite-natureflores.pdf

Carlier, G.I.M., 1948. An all-British mycological culture medium. Br. J. Dermatol., 60: 61-63.

Chaucheyras-Durand, F., N.D. Walker and A. Bach, 2008. Effects of active dry yeasts on the rumen microbial ecosystem: Past, present and future. Anim. Feed Sci. Technol., 145: 5-26.

Chaucheyras-Durand, F. and H. Durand, 2010. Probiotics in animal nutrition and health. Beneficial Microbes, 1: 3-9.

Chen, S.L. and M. Chiger, 1985. Production of Bakers Yeast. In: Comprehensive Biotechnology, Moo-Young, M. (Ed.). Pergamon Press, Oxford, pp: 429-455.

Coppola, R., M. Nanni, M. Iorizzo, A. Sorrentino, E. Sorrentino, C. Chiavari and L. Grazia, 2000. Microbiological characteristics of Parmigiano Reggiano cheese during the cheesemaking and the first months of the ripening. Le Lait, 80: 479-490.

De Dea Lindner, J., V. Bernini, A. de Lorentiis, A. Pecorari, E. Neviani and M. Gatti, 2008. Parmigiano Reggiano cheese: Evolution of cultivable and total lactic microflora and peptidase activities during manufacture and ripening. Dairy Sci. Technol., 88: 511-523.

De Man, J.C., M. Rogosa and M.E. Sharpe, 1960. A medium for the cultivation of Lactobacilli. J. Applied Bacteriol., 23: 130-135.

De Ondarza, M.B., C.J., Sniffen, L. Dussert, E. Chevaux, J. Sullivan and N. Walker, 2010. Case study: Multiple-study analysis of the effect of live yeast on milk yield, milk component content and yield and feed efficiency. J. Profess. Sci., 26: 661-666.

DeVries, T.J. and E. Chevaux, 2014. Modification of the feeding behavior of dairy cows through live yeast supplementation. J. Dairy Sci., 97: 6499-6510.

Desmasures, N. and E. Beuvier, 2011. Partie 1 : Nature et Quantite de Microflores des Laits. In: Microflore du Lait cru: Vers une Meilleure Connaissance des Ecosystemes Microbiens du Lait et de Leurs Facteurs de Variation, Laithie, C. (Ed.)., CNAOL., Paris, France, pp: 15-23.

Desnoyers, M., S. Giger-Reverdin, G. Bertin, C. Duvaux-Ponter and D. Sauvant, 2009. Meta-analysis of the influence of Saccharomyces cerevisiae supplementation on ruminal parameters and milk production of ruminants. J. Dairy Sci., 92: 1620-1632.

EFSA., 2007. Introduction of a Qualified Presumption of Safety (QPS) approach for assessment of selected microorganisms referred to EFSA opinion of the scientific committee. EFSA J., 587: 1-16.
Franciosi, E., F. Gardini, L. Monfredini, G. Tabanelli and A. Fabris et al., 2011. Does milk treatment before cheesemaking affect microbial and chemical traits of ripened cheese? Grana Trentino as a case study. J. Dairy Sci., 95: 5485-5494.

ISO., 2003. Microbiologie des aliments-Methode horizontale pour le denombrement des micro-organismes-Technique de comptage des colonies a 30 $\mathrm{C}$. ISO 4833, 2003. http://www.iso.org/iso/fr/iso_catalogue/catalogue_ics/cat alogue_detail_ics.htm?csnumber $=34524$

ISO., 2004. Microbiologie des aliments-Methodes horizontales pour la recherche et le denombrement des Enterobacteriaceae-Partie 2: Methode par comptage des colonies. ISO 21528, 2004. http://www.iso.org/iso/fr/home /store/catalogue_tc/catalogue_detail.htm?csnumber $=34566$ Marion, D., P. Sylvie, R. Veronique and D. Yann, 2008. Evolution of the raw cow milk microflora, especially lactococci, enterococci, leuconostocs and lactobacilli over a successive 12 day milking regime. Int. J. Dairy. Sci., 3: 117-130.

Mead, G.C. and B.W. Adams, 1977. A selective medium for the rapid isolation of pseudomonads associated with poultry meat spoilage. Br. Poult. Sci., 18: 661-670.

Moallem, U., H. Lehrer, L. Livshitz, M. Zachut and S. Yakoby, 2009. The effects of live yeast supplementation to dairy cows during the hot season on production, feed efficiency and digestibility. J. Dairy Sci., 92: 343-351.

Montel, M.C., S. Buchin, A. Mallet, C. Delbes-Paus, D.A. Vuitton, N. Desmasures and F. Berthier, 2014. Traditional cheeses: Rich and diverse microbiota with associated benefits. Int. J. Food Microbiol., 177: 136-154.

Morris, E.O. and A.A. Eddy, 1957. Method for the measurement of wild yeast infection in pitching yeast. J. Instr. Brew., 63: 34-35.

NRC., 2001. Nutrient Requirements for Dairy Cattle. 7th Edn., National Academy Press, Washington, DC., USA.

Panelli, S., E. Brambati, C. Bonacina and M. Feligini, 2013. Diversity of fungal flora in raw milk from the Italian Alps in relation to pasture altitude. Springerplus, Vol. 2. 10.1186/2193-1801-2-405

Panelli, S., E. Brambati, C. Bonacina and M. Feligini, 2014. Updating on the fungal composition in Sardinian sheep's milk by culture-independent methods. J. Dairy Res., 81: 233-237.

Swan, A., 1954. The use of a bile-aesculin medium and of Maxted's technique of Lancefield grouping in the identification of enterococci (group $D$ streptococci). J. Clin. Pathol., 7: 160-163.

Terzaghi, B.E. and W.E. Sandine, 1975. Improved medium for lactic Streptococci and their bacteriophages. Applied Environ. Microbiol., 29: 807-813. 